Fabri de Peirese", published in 1926, came within the field of science. As he said, "Here we have the phenomenon of an antiquarian who was equally engrossed in medicine and surgery, in astronomy and scientific research". The combination of naturalist and antiquary in his uncle, Edward P. Wright, may have given him a lead in that direction. Through his brother, Sir Almroth Wright, the celebrated pathologist, Sir Charles had many contacts with the scientific world, and he always endeavoured that the committee of the London Library should include scientific men. Alfred Russel Wallace and Sir Archibald Geikie were among the well-known men of science who served in this capacity in his time.

Although the London Library is essentially a library of general scope, its extent implies that it should contain valuable collections of scientific works. Sir Charles endeavoured especially to secure whatever he thought would be of value to future historians of science, and the Library's extensive representation in the history of science and of medicine is of special value to scientific men.

S. C. BradFord.

\section{Prof. S. Lees}

Prof. SAMuel Lees held the Chance chair of mechanical engineering at the University of Birmingham from October 1, 1931, until his death on January 27 last. The son of Alderman S. H. Lees, of Salford, he was born in that town on August 26, 1885. He received his early engineering training at Ferranti, Ltd., of Hollinwood and Charles Churchill and Co., Itd. (afterwards The Churchill Machine Tool Co. Ltd.), of Broadheath, Manchester. Whilst a student of the Manchester School of Technology he gained a Whitworth Exhibition in 1905 and a Whitworth Scholarship in 1906. At about this time he won a prize of $£ 200$, open to technical students generally of Great Britain, offered by Messrs. George Newnes, Ltd., in connexion with their periodical Technics.

After proceeding to Cambridge he took his B.A. in 1909, and later his M.A. He was awarded the Rayleigh and John Winbolt Prizes in 1911, became Hutchinson Student, and was elected in 1912 a fellow of St. John's College. In 1913 he was appointed reader in applied thermodynamics in the Faculty of Technology of the University of Manchester.

From 1915 until 1918 Lees was with the Navy, first as engineer lieutenant and afterwards engineer lieutenant commander. Most of his war service was spent on research work at Portsmouth Dockyard and concluded with a short spell at Farnborough. After the War he returned to Manchester. From 1919 until 1929 he was Hopkinson lecturer in thermodynamics at the University of Cambridge, and for a number of years director of engineering studies at St. John's College. He left Cambridge to become consultant mechanical engineer to Silica Gel, Ltd., and spent some time in Baltimore, U.S.A., on problems concerning the application of silica-gel to industrial uses.
After two years in industry, Lees returned to academic life to take the chair at Birmingham. Here he reorganized the research work of the Department of Mechanical Engineering and was engaged in the investigation of several problems having a bearing upon air-conditioning and upon internal combustion engine theory and practice. These included the aircooling of metal surfaces, heat transmission through metals and loose aggregates, the study of delay-period phenomena in compression ignition engines, catalytic and other methods of improving combustion in engines of this type, exhaust noise in internal combustion engines, electrical methods of indicating highspeed engines and the flow of gases through orifices and nozzles with the view of correlating experimental work with dimensional theory. Some of these researches were in an incomplete but advanced state at the time of his death.

Prof. Lees was a man of unassuming disposition and ineapable of self-advertisement. A first-class teacher, a profound thinker on his subjects, helpful to the point of self-sacrifice to all with whom he was associated, his early death at the age of fifty-four years is a severe blow to the University of Birmingham and to his colleagues, his staff and his students, especially foreign students, who had an affectionate regard for him. He leaves a widow and two sons.

WE regret to announce the following deaths :

Prof. Alfred Bielschowsky, at Hanover, New Hampshire, U.S.A., for many years professor of ophthalmology at Marsburg and Breslau, and a leading authority on motor disturbances of the eye and the physiology and pathology of space sense, aged sixty-seven years.

Prof. Fdouard Branly, the pioneer in radio communication, on March 25, aged ninety-five years.

Mr. E. T. Cottingham, the well-known maker of scientific time-recorders, on March 20, aged seventy years.

Sir Patrick Laidlaw, F.R.S., pathologist to the Medical Research Council, deputy director of the National Institute for Medical Research, on March 20, aged fifty-eight years.

Mr. W. H. Lovegrove, formerly conservator of forests, Kashmir, on January 25, aged seventy-two years.

Prof. E. Mapother, professor of clinical psychiatry in the University of London, formerly medical superintendent of Maudsley Hospital, on March 20, aged fifty-eight years.

Prof. D. S. Margoliouth, F.B.A., Laudian professor of Arabie in the University of Oxford during 18891937, on March 22, aged eighty-one years.

Prof. W. S. Miller, emeritus professor of anatomy in the University of Wisconsin, on December 26, aged eighty-one years.

Prof. Michael Siedlecki, professor of zoology in the University of Cracow.

Dr. Werner Spolteholz, emeritus professor of anatomy in the University of Leipzig, on January 12, aged seventy-nine years. 